\title{
Da sátira obscena ao axioma do frei: poesia romântica e homoerotismo no Brasil (1850- 1864)
}

VAGNER CAMILO

Universidade de São Paulo

\begin{abstract}
This paper addresses the emergence of homoerotic themes in the context of Brazilian romanticism, in poetic works obviously outside or on the margins of the official canon. It also examines the changes from the obscene and satirical verses to the lyric voice in the poems attributed to Moniz Barreto, Laurindo Rabelo and, with special emphasis, Junqueira Freire, author of the only lyric love poem about this theme at the time.
\end{abstract}

Keywords: Brazilian poetry, romanticism, Junqueira Freire, Moniz Barreto, Laurindo Rabelo

Em uma apresentação panorâmica da poesia romântica brasileira, Paulo Franchetti observou, a respeito da produção do frei baiano Luís José Junqueira Freire (1832-1855), "um dos mais importantes de seu tempo," que ela seria "hoje quase ilegível," salvo por um só poema: "De notável mesmo, e curioso, apenas o fato de que é o autor do provavelmente único poema romântico brasileiro dedicado ao desejo declaradamente homossexual, "Eu que te amo tão deveras..." (217). Afora o discutível critério da legibilidade, o crítico talvez esteja certo em afirmar que o poema é caso excepcional e curioso na poesia brasileira do período, a meu ver equiparável, em alguns aspectos, a uma brevíssima passagem de Macário, primeira reescrita fáustica na tradição literária local, em que Álvares 
de Azevedo (1831-1852) ${ }^{1}$ atribui o desejo homoerótico a Satã, quando este carrega o jovem protagonista desfalecido no final da peça: "E como é belo descorado assim! com seus cabelos castanhos em desordem, seus olhos entreabertos e úmidos, e seus lábios feminis! Se eu não fora Satã, eu te amaria, mancebo..." (249). Vale lembrar o comentário de Antonio Candido sobre tal passagem da peça, que pode ser aproximada do poema de Junqueira Freire na reposição de um homoerotismo de ordem socrática, embora Álvares de Azevedo subverta, em boa medida, a kalokagathía, condição sine qua non da relação pedagógica entre mestre (amante) e pupilo (amado).

O relacionamento homoerótico entre mestre e pupilo só se torna digno se possibilitar ao jovem enveredar pelos caminhos das virtudes cívicas. Espera-se que o amante, "na condição de kalokagathós (belo e nobre, virtuoso), conduza o amado ao ponto desejado pela comunidade: o acesso do jovem às virtudes e, portanto, sua ascensão à kalokagathía e à participação na democracia ateniense" (Barbo 49). Ora, Macário subverte essa condição sine qua non por se tratar de uma "aprendizagem do mal":

É interessante que Álvares de Azevedo faça um desdobramento da clássica dupla Homem/Diabo, tão em voga no Romantismo, principalmente sob o avatar mais famoso de Fausto/Mefistófeles - pois aqui Penseroso, Satã e Macário podem ser vistos respectivamente como Homem Angélico, Homem Diabólico e Homem Homem. E é digno de nota que, assim como o Homem Angélico inexiste na primeira parte, nesta [segunda parte da peça] o Homem Diabólico só perpassa, voltando à cena no fim (e aí de maneira decisiva para reorientar a ação), quando o antagonista potencial [Penseroso] morre, e Macário cai de novo sob a sua influência. Esta é bastante complexa e abrange um toque de homoerotismo, sugerido numa fala de Satã carregando o amigo

\footnotetext{
${ }^{1}$ Mais recentemente, Curopos divulgou uma paródia homoerótica do poema "Sonhando", de Álvares de Azevedo. A autoria, no entanto, é desconhecida. Não se sabe, sequer, se concebida por um autor brasileiro, uma vez que essa versão pornográfica saiu no Almanack Caralhal (1860), em Portugal, sete anos depois da publicação póstuma da Lira dos vinte anos. Para o crítico, o poema interessa, sobretudo, como prova de "um diálogo transatlântico queer, "homopaisagens" lusobrasileiras, como lhes chamou Anna M. Klobucka" (Curopos 148).
} 
desfalecido [...]. Talvez se trate de um homoerotismo de tipo socrático, segundo o qual Satã se dedica a formar à sua maneira $\mathrm{o}$ pupilo adolescente. (Candido, “A educação pela noite” 14)

Candido não diz, mas Álvares de Azevedo deve ter buscado inspiração para tal passagem de sua "peça" no final do segundo livro do Fausto goethiano, quando Mefistófeles, embebido por "eflúvios estranháveis," experimenta um desejo semelhante, seduzido pela austera e extrema beleza ("lindamente lindos"), bem como pela sensualidade da falange de anjos, que se valem das mesmas armas do demo para arrebatar-lhe a alma imortal do protagonista e salvá-lo do pacto nefasto. Mefisto deseja vê-los todos nus, mas sente especial atração por um "alto marmanjo," no qual não "orna o ar sonso de padreco," visto o olhar lascivo que parece lhe lançar. Cecile Beurdeley associa tal passagem com as Cartas da Suiça, escritas por Goethe na juventude, nas quais ele "dá uma bela descrição da indeterminação sexual (de que a homossexualidade adulta frequentemente emerge) dos garotos pubescentes. Ele conta como ficou mexido pela visão do corpo nu de seu amigo Ferdinand" (146). Haroldo de Campos, por sua vez, diz que Goethe pôs todo seu engenho malicioso no episódio fáustico, que vale reproduzir abaixo:

\section{MEFISTÓFELES}

A fronte me arde, o peito, o corpo em fogo cruento, Um supra-demoníaco elemento!

$[\ldots]$

Que há comigo?

Têm-me embebido eflúvios estranháveis?

Vejo-os com gosto, esses mancebos adoráveis;

Que me retém? nem praguejar consigo!

E se me ilude a mim tão falso enleio,

Quem, doravante, há de ser o imbecil?

Esses espertalhões que odeio,

Vejo-os manando o encanto mais sutil!

Dizei-me, lindos jovens, pois:

Também da geração de Lúcifer proviestes[;]

Quisera vos beijar, tão sedutores sois, 
Julgo que em boa hora aqui viestes.

Tão natural me sinto e grato,

Como se amigos velhos fosseis e bem-vindos;

Chegais sensuais, mansinhos, como gatos,

E cada vez mais lindamente lindos;

Oh vinde perto, oh concedei-me um vosso olhar!

\section{ANJOS}

Aqui estamos: que te obriga a recuar?

Estamos perto; fica se o puderdes.

(Os anjos, em movimento envolvente, ocupam o

palco todo)

\section{MEFISTÓFELES}

(que se vê impelido para o proscênio)

Tratai-nos de malditos feiticeiros,

Enquanto sois os bruxos verdadeiros,

Pois seduzis vós homens e mulheres. -

Maldita incômoda ventura!

É isso, do amor, a elementar essência?

Meu corpo todo em brasas se tortura,

Mal sinto já da nuca a incandescência.

De cá flutuais, de lá; baixai para o meu plano,

As formas agitai de modo mais mundano,

De fato, o aspecto austero em vós é lindo,

Mas, quisera uma vez, tão só, vos ver sorrindo;

Ser-me-ia um gosto eterno, nunca visto dantes.

Digo: do modo pelo qual se olham amantes,

Dos lábios é um jeitinho, tão somente.

Alto marmanjo, és tu quem mais me agrada;

Não te orna o ar sonso de padreco em nada,

Olha para mim algo lascivamente!

Podíeis sem desonra andar mais nus, aliás;

As amplas vestes são supra-decentes;

Desviam-se, assim vistos, por detrás! 
São os malandros por demais apetecentes. (441-42)

As penas de amor que os anjos adolescentes fazem padecer o velho mestre Satã e seus sequazes, nota Campos, correspondem a um "amor perverso" que volta a assolar, nas reescritas brasileiras da lenda mefistofélica, o fáustico Riobaldo por Diadorim no Grande sertão: veredas (161-62). Descrevendo a carnavalização bakhtiniana do amor nesse episódio goethiano, diz ainda o poeta-crítico concretista:

O amor agora, como a fidúcia jurídica, é também objeto de "carnavalização": é um amor contra legem, contra naturam, 'perverso' (do latim perversus = posto às avessas). A disputa entre o celeste e o diabólico se converte num vale-tudo cósmico, onde todas as armas são lícitas, desde que resultem eficazes para a empreitada salvacionista do leso-demo. Alexandre Arnoux, tradutor do Il Fausto, sublinha [...] "o quadro, tão equívoco do ponto de vista carnal, no qual Mefistófeles se deixa roubar a alma de Fausto pelas Falanges do Paraíso;" no qual o "encanto físico" dos milicianos celestes, "seu sorriso, suas ondulações privam o demo de seus instrumentos e trespassam sua couraça de ódio, amortecem sua esperteza e sua desconfiança, revertem-lhe a corrupção em proveito de Deus e do fracasso da aposta e do pacto." E chama aos legionários angélicos "suaves andrógenos vencedores do Príncipe dos Abismos." O embate entre o "coro angélico," que esparze pétalas de rosas, e Mefisto e sua grotesca tropa de diabos, tem algo de mascarada, de "corso," de batalha de confete entre figurantes de préstitos opostos num desfile de entrudo [...]. No fim da folia cósmica, os "tenentes do diabo" são desbaratados pelo "gay power" do partido dos anjos. Pelo menos são estes os termos da reportagem da derrota, feita pelo prisma de Mefisto, cujo enlevo erótico por seus querubínicos antagonistas envolve representações de eunuquismo, travestimento e "striptease." (159) 
Busco demonstrar, adiante, como Junqueira Freire repõe essa matriz socrática no trato com a matéria homoerótica, sem, é certo, a subversão fáustica que a aprendizagem do mal de Macário promove ao atribuí-la à pedagogia de Satã. Antes disso, interessa atentar ao quanto o poema freiriano diverge do tom dominante até então na abordagem do homoerotismo. Nesse sentido, reformulando a hipótese de Franchetti, pode-se dizer que o caráter de exceção do poema freiriano no contexto do romantismo brasileiro se deve não à abordagem do tema, mas, antes, à mudança de registro empregado ao abordá-lo.

A herança poética que vinha da colônia, pelo que sei, só parecia ocupar-se do assunto em clave satírica, a exemplo dos poemas atribuídos a Gregório de Matos (1636-1696), em que o tratamento é sempre depreciativo, como prática bestial, configurando uma ofensa a quem se quer desqualificar, independentemente de o alvo do ataque ser ou não homossexual. ${ }^{2} \mathrm{O}$ tema volta a ser abordado nesse tom rebaixado na Bahia contemporânea de Junqueira Freire - portanto já no quadro histórico em que o romantismo domina a cena-por dois outros nomes que mantiveram, em paralelo à obra poética oficial, uma produção satírico-obscena. Refiro-me a Francisco Moniz Barreto e Laurindo Rabelo, amigos próximos de poeta-frei e partilhando, todos, do mesmo ambiente (de sociabilidade predominantemente masculina, é claro) que possibilitava a abordagem de tal ordem de assunto, independentemente do tratamento dado a ele. ${ }^{3}$

Entre vários poemas obscenos de Moniz Barreto e Laurindo Rabelo, pode-se verificar que alguns parecem, na verdade, proceder do corpus atribuído a Gregório de Matos. Como muito do que foi preservado ou, também, atribuido especialmente a Rabelo chegou por mão de terceiros, recolhido, a dada altura, em edições clandestinas, é de se supor que a autoria tenha se confundido nas águas da memória. A lógica da "movência," no sentido em que a definiu Zumthor, alcança aqui a própria atribuição de autoria. ${ }^{4}$ Está visto que tomo, com

\footnotetext{
${ }^{2}$ Em diferentes momentos de seu estudo, João Adolfo Hansen examina as ocorrências do "vício nefando da sodomia" (332) e sua determinação teológica na sátira atribuída a Gregório de Matos (e em outros documentos contemporâneos a ela).

${ }^{3}$ Embora nascido no Rio de Janeiro, Laurindo Rabelo (1826-1864) deslocou-se para a Bahia quando iniciou os estudos de medicina. Sobre o grupo baiano ligado a Moniz Barreto (1804-1868), do qual faziam parte Rabelo e Freire, veja o que registra Silvio Romero em diferentes passagens de sua História da literatura brasileira. Ver também a descrição desse grupo baiano feita por Homero Pires, em especial, os capítulos "Segunda escola baiana" e "Vida literária" (187-212).

${ }^{4}$ Barreto chegou a organizar seu Álbum da rapaziada, pelo qual foi condenado, apesar dos cuidados em ocultar a autoria com a inversão das iniciais do nome e com a atribuição da publicação a outro
} 
Camilo

certa liberdade, a definição dada pelo grande medievalista suíço, em diálogo com a concepção de "tradicionalidade" de Menéndez Pidal, como "assimilação do mesmo," procedendo da "ação contínua e ininterrupta das variantes." Zumthor afirma que, ao contrário da transmissão puramente escrita, a oralizada combina "reprodução e mudança: a movência é criação contínua" (145). Na produção aqui examinada, além das variantes, há também essa mudança na atribuição de autoria, o que, inclusive, ajudaria a rever certa polêmica da historiografia literária em relação à suposta "desaparição" de Gregório de Matos da tradição poética, da perspectiva do século XIX. Talvez sua presença se mantenha aí, em boa medida, nessa tradição satírico-obscena transmitida em parte oralmente, mas com o apagamento ou mudança da autoria que, em seu tempo, não tinha valor algum, conforme demonstrou Hansen no estudo citado. De modo problemático, Pires fala deliberadamente em imitação de Gregório de Matos (1636-1696) em algumas sátiras de Moniz Barreto, ao caracterizar o ambiente literário e político baiano da época (189).

Seja como for, voltando ao tema deste ensaio, importa observar a visão depreciativa do homoerotismo, o que, certamente, não era exclusiva da sociedade patriarcal brasileira. À concepção de prática bestial, associa-se a demonização e, como consequência lógica, a danação como paga no reino de Plutão, conforme se vê nos sonetos do Álbum da Rapaziada (1864), de Moniz Barreto. ${ }^{5}$ Embora já comparecesse na mitologia clássica como temido deus das profundezas, os escritores cristãos da antiguidade tardia e as mitologias medievais escritas em latim, dando continuidade à confluência de deidades gregas e romanas iniciadas pelos antigos romanos e agora associada também aos relatos míticos cristãos, tornaram o líder do submundo clássico um aliado ou duplo do Diabo ou Lúcifer (Solmsen). Algo dessa confluência comparece no Plutão de Moniz Barreto: se a

país, como era comum se fazer a época. Ver o que relata Homero Pires a respeito do Álbum (204ss). Já no caso dos Poesias livres de Laurindo Rabelo, é mais discutível a questão da edição, de que trato em Risos entre pares (125-28). Importa notar que Constâncio Alves, em 1931, relata o fato de o poeta, próximo da morte, ter pedido que algumas das sátiras constantes desse volume não fossem publicadas pelos dissabores que lhe causaram, mas "o interesse mercantil de não sei quem contrariou a vontade do morto" (Rabelo, Obras completas 198).

${ }^{5}$ Como lembra ainda Campos, apoiado em Frye e Barthes, "por um processo de expurgo mitopoético, as 'altas religiões' tendem a limitar suas visões apocalípticas ao moralmente aceitável; assim, 'enquanto a poesia segue a religião na direção da moral, os arquétipos poéticos e religiosos permanecem estreitamente ligados, como em Dante; sob tal influência, a imagética sexual apocalíptica tende a ser matrimonial ou virginal; a incestuosa, a homossexual e a adúltera recaem do lado do demônio" (159). 
deidade e outras referências míticas evocadas nos versos são herança da tradição clássica, o pretenso horror e furor na perseguição à "pederastia" parece, em boa medida, tributárias da condenação, pela moralidade cristã, do que a Igreja passou a denominar de "sodomia," com respaldo do Velho Testamento. ${ }^{6}$ Veja-se um dos poemas do Álbum da rapaziada sobre o tema, cuja menção final ao "cão tinhoso" reforça essa associação entre cristianismo e mitologia clássica:

\section{PLUTÃO}

( $A$ um sacana mor, que entrou no inferno)

\section{SONETO}

Vem cá, puto de merda, sem vergonha, De que enfim, viu-se o mundo aliviado! Eu mesmo, de te olhar, horrorizado, Não sei, para punir-te, onde te ponha.

Trazes ainda de viril peçonha Suja a destra, e o roto cu babado! Inimigo dos conos! Desgraçado! Escuta a pena, que vais ter, medonha.

Co'a tua infame profissão nociva

De muitas almas me roubaste o gozo, E a posse que da cópula deriva...

Pois bem: para castigo teu penoso, Co’a mão aberta sempre em chaga viva, Irás pívias fazer ao cão tinhoso. ${ }^{7}$

É notório que a imagem do demo evocada por Plutão no poema nada tem a ver com as feições antropomórficas conferidas a Satã desde Milton até a grande

\footnotetext{
${ }^{6}$ Lepage 203-24. Como exceção à regra, Curtius lembra que, em meio à condenação geral à sodomia e à queixa contra os vícios pela doutrina cristã, alguns textos de fins do século XI e começo do seguinte atestam uma desenvoltura erótica no trato com o tema também no alto clero, muito provavelmente em círculos humanísticos (159-63).

${ }^{7}$ Reproduzo os poemas do Álbum da rapaziada, de Moniz Barreto, tal como constam da transcrição do livro em anexo à dissertação de Pellegrini (206).
} 
beleza e o figurino elegante (quase um dandy!) do de Álvares de Azevedo. Essa antropomorfização é correlata ao processo de interiorização progressiva do mal, reconhecido pelas diversas filosofias do sujeito como parte constitutiva da natureza humana (Muchembled 238). Já o "tinhoso" de Moniz Barreto mantém a imagem bestial (pura alteridade) criada pelo imaginário cristão e reiterada pelas figurações medievais dos autos e outros gêneros literários.

O soneto é estruturado numa forma dialógica, com a voz poético-satírica delegada ao próprio senhor dos infernos, cujas interpelações diretas vão do vitupério ("puto de merda," "sem vergonha," "desgraçado") à maldição das mais cruéis! Aqui, a dimensão perversa diverge substancialmente da referida por Campos no caso de Mefisto goethiano, tomando o termo no sentido etimológico. Para ser mais preciso, o castigo decretado por Plutão é da ordem não propriamente da perversão, mas da perversidade, como se nota no último terceto.

Além de iniciar a enfiada de insultos logo na primeira quadra, Plutão irmana sua visão preconceituosa à do "mundo" para enunciar o "horror" partilhado com a comunidade da "rapaziada" a que se dirige diante da prática sexual condenada. $\mathrm{Na}$ verdade, a persona satírica encena a própria dificuldade de encontrar em seus domínios onde alocar o "sacana mor," o que pressupõe que o suposto "crime" por que é condenado não tem lugar no catálogo dos pecados previstos, muito embora se saiba que a civilização judaico-cristã, desde a Idade Média, já havia instalado a sodomia, como vício "contra natura," no topo de todos os pecados de luxúria, por impedir a multiplicação da espécie e constituir, assim, "um atentado direto à lei do ser" (Lepage 204-05). Afinados com essa concepção cristã, poetas como Dante (103) condenam os sodomitas ao terceiro giro do sétimo círculo do Inferno, ao lado de outros acusados pelos pecados da violência e da bestialidade. E pela ofensa a Deus ao agirem contra a ordem da Natureza criada por Ele, são queimados sob chuva de chispas de fogo, correndo sem parar sobre um areal incandescente, o que, segundo os intérpretes da Divina Comédia, representaria, em um nível mais baixo, a punição dos luxuriosos do segundo círculo. Uma variante desses castigos ígneos reaparece no segundo soneto de Moniz Barreto, com o "braseiro" como "cama dos réus de leso-cono."

Retornando, por ora, ao soneto acima, a segunda estrofe apresenta imagem grotesca da prática homoerótica em registro escatológico, com o esperma associado à ideia de sujeira ("Trazes ainda de viril peçonha / Suja a destra, e o roto cu babado!"). No último terceto, a visada heteronormativa de Plutão enuncia 
a punição ou "pena medonha" contra o "inimigo dos conos." Antes disso, no primeiro terceto, Plutão caracteriza a prática homoerótica do tal "sacana mor," alvo da investida satírica, como "infame profissão". Não se sabe, ao certo, se o satirizado vivia, de fato, de sexo mediante pagamento, ou se a prática homoerótica por si só já é rebaixada à condição de "profissão nociva". Seja como for, o que incomoda ainda mais Plutão é o fato de o satirizado disputar com o senhor dos infernos - ou mesmo roubar-lhe - o gozo com o aliciamento de muitas almas. Talvez movido por esse ódio da disputa é que Plutão lança o "castigo penoso" quase no fecho de ouro dos versos: a masturbação infindável do próprio "cão tinhoso" com a mão "aberta em chaga viva." Reverbera aí a condenação da Igreja não só à sodomia, como também às práticas masturbatórias. Em suma, como se vê, embora o mito seja romano, a visada discriminatória é absolutamente cristã na condenação do "crime nefando" que, entretanto, é descrito com todas as minúcias.

Vale registrar que, apesar de atribuída a Plutão, essa visada encontra reforço na voz que segue em paralelo ao poema, em nota de rodapé indicada por asterisco no último verso soneto, que profere, igualmente, o seguinte comentário inflamado: "Apoiado, Sr. Plutão! Apoiadíssimo! Esfregue-me, sem compaixão, esses salafrários, e quantos outros descarados e patifes de diversos gêneros the caírem nas unhas: fogo neles!” (206). ${ }^{8}$ A voz que tende, de saída, a ser associada ao próprio poeta (ainda que se possa discutir seu maior ou menor grau de ficcionalização), reitera os vitupérios e incita à comunidade a que se dirige efetivamente (no caso, a rapaziada do título do livro, embora interpele diretamente Plutão) a partilhar do ódio generalizado ao tipo que o alvo da sátira representa nos versos acima.

Da interpelação direta e da condenação sumária por parte do senhor do submundo (e supostamente do próprio poeta, cuja voz ecoa em nota), passo a outro soneto que também recorre à forma dramatizada - mais acentuada ainda por causa da estrutura aparentemente dialogada. De novo, Plutão se dirige a "um fanchono" que não se sabe, ao certo, se é o mesmo do poema anterior. De todo modo, os versos mostram-no chegando às portas do inferno, onde é igualmente mal recebido por Plutão e travam, ambos, um suposto diálogo, antes de o deus dos infernos proferir a sentença, que nada fica a dever à anterior em matéria de

\footnotetext{
${ }^{8}$ Sobre a função das notas de rodapé no Álbum da rapaziada, ver Pellegrini (113).
} 
perversidade. Reproduzo, abaixo, o poema, que também vem acompanhado não de uma, mas três notas de rodapé, reiterando o horror da voz poética diante da homossexualidade e buscando, da mesma maneira, a cumplicidade do público a que está endereçado o soneto anterior:

\section{O MESMO E UM FANCHONO}

\section{SONETO}

Plutão-O que busca por cá, senhor fanchono?

Acaso de algum puto vem ao cheiro?

Ou também quer comer-me, sô brejeiro,

A mim que sou desta morada o dono?

Fanch-Não senhor; venho aqui dormir meu sono...

Plutão-O quê? Dormir, patife?! Travesseiro

E colchão dar-te-ei, mas num braseiro,

Que é a cama dos réus de leso-cono. ${ }^{1}$

Leva daqui, Megera, este birbante; ${ }^{2}$

$\mathrm{Tu}$ e as tuas irmãs, com fúria brava,

Pena lhe inflijam, que ao meu reino espante:

Na boca, que mulheres não beijava,

Mijem-lhe todas três, de instante a instante,

De chumbo derretido ardente lava. ${ }^{3}$

${ }^{1}$ Este "leso" não pode ser tomado senão no sentido moral; isto é, de ofensa resultante do menoscabo, ou da preterição, que muitas vezes sofre de alguns desalmados o altar precioso de Vênus: não é assim, rapaziada?

${ }^{2}$ Uma das três fúrias do inferno, segundo a fábula.

${ }^{3}$ É bem natural que as tais Senhoras Eumênides não urinem, como as belas cá deste mundo, água, mais ou menos pura, e sim chumbo e outros metais em fusão. (207) 
Falei em uma estrutura aparentemente dialogada por causa da assimetria evidente das falas. Resta ao dito "Fanchono" um só verso. Os treze versos restantes pertencem a Plutão, cuja voz imperiosa persiste na investida violenta, com condenações e maldições similares às do soneto anterior nos requintes de perversidade. Isso é visível na enumeração das penas, que vão do braseiro como "cama dos réus de leso-cono" ao mijo das três Fúrias na boca, "que mulheres não beijava," do "birbante," mijo logo convertido em lava ardente de chumbo derretido. Das três irínias (outro nome para Fúrias ou, eufemisticamente, Eumênides, como prefere o poeta em nota), Plutão convoca Megera, que assume a frente da empreitada vingativa, personificando não tanto o rancor, a inveja, a cobiça e o ciúme, como ocorre em diversas vezes em que essa figura mitológica é evocada. Ela comparece aqui, muito mais, como a que castiga principalmente os delitos contra o matrimônio, sobretudo a infidelidade. É a Fúria que persegue com a maior sanha, fazendo a vítima fugir eternamente, gritando-lhe aos ouvidos as suas faltas.

Importa destacar a ironia presente na primeira quadra. Ao indagar sobre o que o "senhor Fanchono" buscava no inferno, supõe que ele vinha "ao cheiro de algum puto" ou, hipótese mais curiosa, de que o "sô brejeiro" quisesse, talvez, "comer" o próprio "dono desta morada." Apesar da negativa do satirizado, é curioso que Plutão, dado o tamanho e furibundo horror diante da sodomia, chegue a aventar, mesmo que ironicamente, tal hipótese.

Além dos dois sonetos, a referência satírica à sodomia desponta de passagem em outro momento da obra do repentista baiano ${ }^{9}$. Entretanto, os dois sonetos brevemente apresentados são suficientes para se aquilatar o tratamento dominante dado ao tema à época. E vale para comparar com outro exemplo, igualmente fescenino, praticado pelo poeta lagartixa: o amigo e conterrâneo Laurindo Rabelo, que dizem ter travado duelos poéticos com Moniz Barreto. Supõe-se, inclusive, que Rabelo aprendeu a versejar de improviso, à maneira popular dos cantadores, com o autor do Álbum da rapaziada. Os dois encarnavam, então, o exemplo acabado de "poetas de praça pública" (Broca 6972).

\footnotetext{
${ }^{9}$ É o que se observa, ainda, em "Quer cono," um dos “Aforismos poéticos" do Álbum da rapaziada, que traz um "Caixeiro, que está na loja / Com requebros de fanchono" (230).
} 
Já tive a oportunidade de comentar, em outro momento, algo dessa produção do poeta lagartixa, como foi chamado um dia. Interessa apenas enfatizar o que observara, então, a respeito da representação homoerótica: ao contrário de seu mestre repentista, Laurindo Rabelo não revela, propriamente, a mesma indignação e o tremendo horror expressos pelo primeiro em relação à sodomia. Isso a ponto de o próprio eu poético aparecer frequentemente desejando tal prática, quando não entregue a ela de forma efetiva, com naturalidade e grande prazer! Portanto, já não se trata mais da atitude distanciada, indignada, judiciosa que define a conduta pretensamente irreprochável da persona na sátira tradicional, da qual parece se aproximar Moniz Barreto, embora essa indignação diante do tipo e do comportamento satirizado, somada ao tom exaltado, raivoso, tendam a ser postas sob suspeita quando ele trata de atribuir a voz à figura demonizada de Plutão. ${ }^{10}$ No caso de Rabelo, longe de tamanha indignação, o caráter moralizante da sátira parece, até certo ponto, abandonado, pelo menos nos poemas livres que se vê a seguir.

Começo por uma décima, no esquema popular de mote e glosa, em que o eu já aparece naturalmente entregue à prática homoerótica em meio à praça pública ou, mais especificamente, atrás de uma barraca de festa:

\section{MOTE}

Porro no cu não é festa.

\section{GLOSA}

Em noite do Esp'ríto Santo

Comia certo fanchono

Um sacana de alto abono

De uma barraca no canto;

Já lhe tinha um tanto ou quanto

Entrado do cu na fresta;

Troam foguetes... "E esta?"

\footnotetext{
${ }^{10}$ Para uma definição mais preliminar e sucinta da sátira e da "persona satírica," sua pretensa franqueza, seu didatismo, sua tendência autopromocional como juiz da moral e das condutas, ver o verbete sobre esse (sub-) gênero em Preminger e Brogan (1114-17). Para um exame mais detido sobre as convenções típicas do gênero, consulte-se Kernan, e, quanto às duas tendências da sátira, a de tom exaltado, raivoso de Juvenal (do qual parece se aproximar Moniz Barreto), por oposição à urbanidade horaciana, Hodgart (134).
} 
(Diz o puto em repiquetes)

"A que vêm estes foguetes?

Porra no cu não é festa!" (Poesias livres 12) ${ }^{11}$

Chama a atenção a cenografia construída para a abordagem de tal tema. É curiosa a estreita associação instituída entre tal prática e o ambiente de festejo popular. Um festejo, vale notar, de caráter religioso, já que se trata de noite de Espírito Santo, referência à Festa do Divino, no dia de Pentecostes, uma das mais tradicionais do folclore brasileiro, vinda para o Brasil com o colonizador e aqui assumindo um caráter híbrido, misturando manifestações religiosas e profanas. Todavia, a dimensão profana não recobre a natureza profundamente religiosa do festejo, o que dá ao ato sexual descrito um caráter algo sacrílego. E tanto mais ímpio ou divertidamente blasfemo porque, à festa do Divino, faz eco a outra "festa" metaforicamente descrita no mote que a décima acima glosa: "Porra no cu não é festa!" O humor é alcançado pela convergência entre o troar dos foguetes, no ápice da festa, juntamente com o ápice do gozo sexual expresso na fala entrecortada em repiquetes do "sacana de alto abono."

Vale atentar para seu estatuto social, que parece contrastar com o lugar de classe de onde fala a persona, aliás não só aqui, mas em outros momentos das Poesias livres. Além disso, a ênfase dada a esse estatuto social e o modo ofensivo de se referir a tal "fanchono," chamado ainda de "puto" e "sacana," poderiam conferir ao poema o feitio de uma invectiva satírica. Todavia, o fato é que, reitero, a persona se deixa flagrar aqui, despudorada e livremente, entregue, sem mais, à prática homoerótica, num ato desinvestido de qualquer intenção moralizante caraterística da sátira, que continua a despontar em Moniz Barreto. Essa dimensão moralizante da sátira tradicional apaga-se ainda mais em outros poemas, na medida em que o eu adotado pelo poeta lagartixa fala mais abertamente da beleza do rapaz e da vontade de possuí-lo.

Veja-se este poema em que o desejo homoerótico vem associado não à persona, mas a um outro deus mitológico bem distinto do Plutão de Moniz Barreto:

\section{OUTRO}

\footnotetext{
${ }^{11}$ Todos os poemas de Rabelo foram reproduzidos de acordo com a edição das Poesias livres, a que tive acesso pela cópia xerografada gentilmente cedida por José Ramos Tinhorão.
} 
Priapo teve um ataque ao ver um donzel no mundo.

\section{GLOSA}

Dos conos no grande saque,

Que é por todos repetido, Nas lutas enfraquecido, Priapo teve um ataque;

O deus tornou-se um basbaque, $\mathrm{E}$ as putas com dó profundo Puseram luto no sundo; Mas tudo em breve mudou, Porque o deus ressuscitou ao ver um donzel no mundo. (Poesias livres 28)

O deus da fertilidade, tradicionalmente representado na forma itifálica, aparece aqui "enfraquecido" nas lutas, possessões e saques, e, por fim, tem "um ataque." A imagem da impotência leva as prostitutas ao lamento-elas que eram, desde a antiguidade, as principais cultoras desse deus da arraia-miúda, como garantia mesmo de ter clientes para o exercício da profissão. É João Ângelo Oliva Neto quem esclarece esse status mais humilde de Priapo, deus de pobres, pescadores e, inclusive, prostitutos e prostitutas do baixo meretrício. Estas últimas adoramno porque o desejo dos homens que o deus desperta fá-los (o trocadilho vem a calhar) procurá-las, garantindo-lhes o ganho financeiro. Por isso ficam agradecidas a Priapo, conforme exemplifica a Priapeia latina 34, um poema votivo em que a votante é uma prostituta: "Ao culto ao deus lascivo uma menina / que não custava muito foi levada, / p'ra toda ser de todos em comum. / Quantos homens pegou numa só noite, / tantas picas de vime te dedica" (225). ${ }^{12}$

Ao contrário, porém, dos versos acima, nos de Rabelo, o "deus tornou-se um basbaque." Em função disso, as "putas" com "dó profundo / puseram luto no sundo" (que como a cona, era designação obscena então comum para o órgão sexual feminino). Mas se Priapo, impotente, revela inapetência para a prática heterossexual, o desejo é ressuscitado diante da visão "de um donzel no mundo."

\footnotetext{
${ }^{12}$ Agradeço a Oliva Neto os comentários e sugestões feitas às análises aqui propostas.
} 
A associação do deus da fecundidade com a "pederastia" não é pura invenção do "poeta lagartixa." No longo estudo e antologias que organizou sobre as priapeias grega e latina, Oliva Neto registra um epigrama pederástico em que um belíssimo jovem desperta o desejo amoroso de Pã e Priapo. No caso da Priapeia latina, "vários epigramas assumem matéria pederástica quando Priapo ameaça violentar por coito anal ou oral o ladrão que for rapaz" (135-36). Oliva Neto traduz também uma inscrição latina em que o autor saúda "Priapo, santo pai de tudo," pedindo que lhe conceda a "florida juventude" para que ele "possa dar prazer, com falo / resoluto, a meninos e meninas" (27).

Pode-se aproximar, ainda, um exemplo da priapeia em língua portuguesa, lembrando a sátira genial de Bernardo Guimarães ao indianismo gonçalvino em o "Elixir do pajé," pois quando o piaga recobra sua potência sexual, graças à triaga de plantas cabalísticas, ele investe sexualmente, de forma indiscriminada, contra índias e índios. É o que se nota nesta passagem, que rebaixa a matéria épica e o tom marcial do modelo indianista à satiríase, ao descrever as proezas do pênis guerreiro:

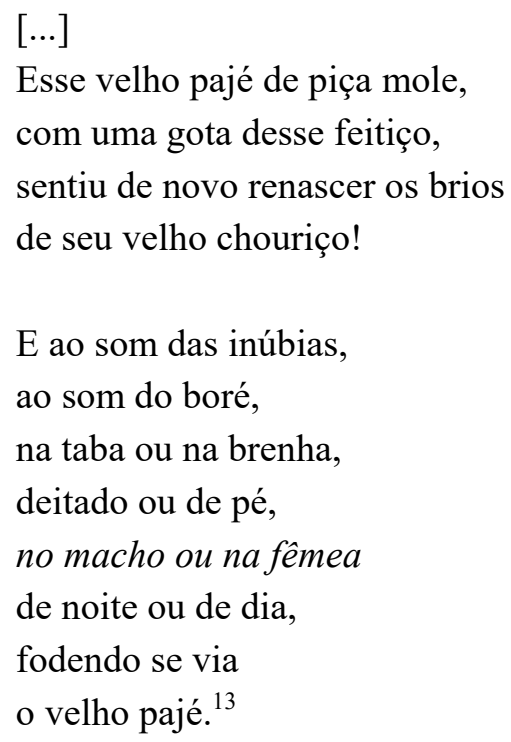

${ }^{13} \mathrm{O}$ verso em destaque é reiterado em dois outros momentos, além da referência à relação anal em "Vassoura terrível dos cus indianos" (Guimarães 53-55). Examinei em outro momento, com mais vagar, os procedimentos característicos da concepção desse poema, seu contexto de produção e circulação, bem como a visada crítica da paródia gonçalvina (Risos entre pares 137-47). 
A reportação ao deus Priapo também pode, implicitamente, ser referência à própria persona do poema de Rabelo e a seu desejo por um "donzel." O eu aparece, assim, referido metonimicamente (tal como as mulheres reduzidas à "cona" ou ao "sundo"), objetivado no seu órgão ora impotente, ora ressuscitado. E aqui, vale uma última observação de Oliva Neto sobre as transformações operadas na representação de Priapo, bem como as significações que elas passam a conotar:

Priapo pode possuir membro enorme, não necessariamente fálico [...]; depois é dotado de falo, que se torna tão grande quanto o próprio deus e até maior do que ele, para enfim tomar de assalto seu corpo inteiro de modo tal que os demais traços antropomórficos lhe ficam subordinados: aqui a parte se faz todo, o falo, parte do ser, falo cuja condição anatômica de estar ereto no homem é ainda situação passageira e circunstancial, passa a ser no deus parte principal, perene e até todo o ser, isto é, o passageiro torna-se duradouro, a contingência torna-se necessidade [...]. A amplificação do falo, que parece desvelar a virtude de uma superlativa masculinidade-'o caralho' hoje se diz do que é notável - pode trair na verdade só a redução viciosa da inteira condição humana, da qual o sexo masculino é parte. (30)

Veja-se, agora, duas outras décimas atribuídas a Rabelo, nas quais a persona entra em cena e explicita, de modo bastante enfático e detalhado, seu desejo homoerótico, que vai além da penetração. O primeiro poema, inclusive, confere ao episódio a cor local do escravismo (sempre aviltante, ainda quando se busca conferir graça à cena), no momento em que "o senhor moço" se reporta de modo desrespeitoso à "preta" ("cachorra") por ela se recusar a intermediar o assédio ao belo rapaz que ele deseja imensamente possuir. ${ }^{14} \mathrm{E}$ dela que parte a glosa do mote:

\footnotetext{
${ }^{14}$ Em outros momentos das Poesias livres de Rabelo, assim como no Álbum de Barreto, comparece a visão bestializada da negra ou da "mulata," como dizem ambos, similar ao que ocorria na sátira de Gregório de Matos. Se, no contexto da sátira setecentista, a desqualificação genérica, conforme as tópicas "raça" e "origem," são explicadas por Hansen de acordo com as convenções retórico-
} 
MOTE

Não posso mais aturá-lo!

\section{GLOSA}

Vi por uma fina greta

De um rapaz o lindo rosto;

Fiquei morrendo de gosto,

Quis come-lo de punheta.

Nisto passou uma preta,

Que ia talvez procurá-lo;

Mandei por ele chamá-lo,

Mas respondeu-me a cachorra:

- Meu senhor moço, ora porra!

Não posso mais aturá-lo! (63)

\section{OUTRA}

Tinha a pica intrometido

Já toda no cu de um puto,

E pelo pentelho hirsuto

Tinha a destra introduzido;

Diz-me o puto mui doído:

- Meu senhor, queira tirá-lo!

Eu aperto-lhe o badalo,

E o puto, então se zangando,

Grita, a bunda retirando:

— Não posso mais aturá-lo! (64)

Nas duas décimas estruturadas como glosas de um mesmo mote, tem-se, primeiramente, o eu poético entrevendo pela frincha ou, em termos muito sugestivos, pela "fina greta," o rosto lindo do rapaz, o que faz suscitar o desejo não apenas de penetrá-lo. A expressão "comê-lo de punheta" parece criar certa

poéticas e as concepções teológico-políticas então reinantes numa ordem absolutamente conservadora, a sua reposição, sem mais, num outro contexto como o oitocentista, torna-se problemática e mereceria uma consideração mais detida, que não cabe aqui. 
ambiguidade. De imediato, faz pensar que o eu se masturba enquanto fantasia ou imagina que está penetrando o rapaz. Mas o fato é que não parece querer só isso, tanto que pede à mulher para que interceda, chamando o rapaz. Nesse sentido, talvez a expressão queira significar algo mais no poema.

Enfim, seja qual for o sentido, quando se considera isoladamente o primeiro poema, o desejo ardente do eu parece se frustrar com a recusa da personagem feminina de intermediar o contato com o rapaz. Já no segundo poema, unido pelo mesmo mote, vê-se o eu na iminência de satisfazer seu desejo. O poema começa, por assim dizer, in medias res, pois a persona aparece, de saída, em pleno ato (e as aliterações das consoantes plosivas ajudam a sugerir ainda mais isso), já tendo penetrado o agora denominado "puto" (em vez de o "rapaz de rosto lindo" do poema anterior). Mas seu desejo vai além: quer também masturbar o rapaz ao mesmo tempo que o penetra. Porém, quando sua mão, em meio ao "pentelho hirsuto," está próxima de tocar o membro do outro, este, sentindo dor pela penetração, pede para que o eu retire o pênis, interrompendo o coito. Desejando seguir no seu intento, o eu reage, persistente ou muito inconvenientemente, apertando-lhe o "badalo" (o pênis ou a área mais sensível do escroto), levando, de vez, à irritação do rapaz que, de modo abrupto, "a bunda vai retirando." O mote é, agora, empregado por este último, para pôr fim ao ato sexual, já quase em vias de consumação.

Embora o desejo se frustre em ambos os poemas, não se pode desconsiderar que o eu criado pelo "poeta lagartixa," repito, é posto em cena ou flagrado não só enunciando o desejo homossexual, mas praticando-o efetivamente, penetrando e masturbando outro rapaz, ao contrário da persona satírica indignada e moralista de seu mestre Moniz Barreto que, sempre à distância, lança vitupérios e condenações das mais perversas. De todo modo, os poemas de Rabelo não representam uma mudança efetiva de tratamento na abordagem poética do homoerotismo, coisa que só parece ocorrer mesmo no período em questão com o poema do frei beneditino, que encarnou em seu meio o retrato, novo e insólito na literatura brasileira de então, do poète damné — atitude justificada em vista da rebelião contra a vida monástica que erroneamente abraçou. ${ }^{15}$

\footnotetext{
${ }^{15}$ Reproduzo um lugar comum (sempre discutível) da historiografia literária, assim sintetizado por Candido: "O erro de vocação que o levou ao claustro onde não se pode aquietar; o horror do celibato; o desejo reprimido que o perturbava e aguçava o sentimento do pecado; revolta contra a regra e o mundo; a revolta contra si próprio; o remorso e, como consequência natural, a obsessão
} 
Passo, finalmente, à mudança de registro operada pelo poema de Junqueira Freire, posto em circulação, pelo que sei, por Homero Pires, na biografia que dedicou ao poeta-frei beneditino. Pires, aliás, numa pretensa análise "psicanalítica," na verdade, tributária de concepções há muito suplantadas, ao traçar o "caráter" e o "retrato psicológico" do poeta, vê no poema em questão"furtivamente" transcrito "como num desvão"-mais uma prova de "um temperamento, no qual tinha grande parte o instinto sexual [...]. Não era absolutamente um normal" (334). ${ }^{16}$

De acordo com o biógrafo de Junqueira Freire, o poema consta de um caderno de 40 páginas numeradas e manuscritas, intitulado Miscelânea e datado de 1850. Informa ainda que o poema aparece escrito à margem de uma página "em letra excessivamente miúda" (333-34), sendo datado de 9 de outubro do referido ano. Reproduzo abaixo o poema tal como consta dessa biografia, mantendo a ortografia de então, em respeito a certas rimas e aliterações:

Eu que te amo tão deveras, A quem tu, louro moçolo, Me fazes chiar e amolas, Qual canivete em rebolo; Eu que, qual anjo, te adoro, Então, menino, eu sou tolo?

da morte" (158). Por isso, Merquior fala de "nosso único ultra-romântico efetivamente damné, o beneditino baiano Junqueira Freire, que viveu três anos o drama do religioso sem vocação, moralmente encarcerado" (77).

${ }^{16}$ Pires alinha o poema ao lado de outros, em registro erótico ou mesmo obsceno, deixados dispersos por Junqueira Freire, nos quais o poeta achava "um meio de extravasar [...] com todo o seu ímpeto [...] a porção de lubricidade, que se contém na poesia Temor" (293). É possível, nessa perspectiva, que Pires e talvez outros intérpretes, ainda ligados a concepções biografizantes, tenham visto no poema "Eu que te amo tão deveras" um "sintoma" de uma homossexualidade reprimida e ocultada, constituindo mais um dos "segredos" que levara o poeta-frei a buscar refúgio na ordem monástica. Sobre tais "segredos," ver o capítulo seis da referida biografia. Mott, por exemplo, conclui pela homossexualidade de Junqueira Freire com base nesse poema, conforme se deduz do verbete sobre o poeta. Muito embora o romantismo tenha favorecido a intérpretes mais apressados esse tipo de associação mimética entre vida e obra, ela é sempre problemática e objeto de desconfiança. Mesmo que não se espose, por outro, a dissociação mais radical proposta por algumas correntes da teoria poética, quando insistem no caráter ficcional do personagem que assume a voz lírica, há sempre um grau de indeterminação na relação entre o eu lírico e o sujeito biográfico que não pode ser desconsiderada sem mais. Para um debate mais recente sobre a questão, ver Culler (104). 
Quem te venera e te serve,

Te serve de coração;

Quem a nada mais atende,

Senão á sua paixão;

Quem sustém por ti a vida,

Tolo não póde ser, não.

Quem te olhando a aurea face,

Lá se queda enamorado,

Te olhando os olhos ferventes,

Permanece endeosado;

Esse que chamel-o tolo,

Esse sim—vae enganado.

Quem tanto por um só perde,

Que a ninguem quer antepol-o,

Que vel-o só quer num throno,

Num throno só d'ouro pol-o;

Esse que tolo xingal-o,

Esse sim—esse é que é tolo.

Quem ia em ver seu queixinho

Bipartido se mantém;

Quem embebido em seu todo

Horas, dias gasto tem;

Quem no carcere do corpo

A alma por elle sustém;

Avanço axioma certo,-

Que esse não é tolo, não;

Que esse ama angelicamente

Fora da contagião;

Que esse que tolo xingal-o,

Esse sim-é toleirão. 
E tu me xingaste tolo,

Meu moço, anjinho feliz!

Só porque amar-te devéras

Meu Deus, minha sina quiz.

Só porque certo bem maus

Dous versos te dei que fiz.

Meu anjo me olha e despreza

Com mirar tão furibundo!

Já não hei mais esperança

De ter seraphim jucundo,

Que aos Céus me leve risonho,

Quando me fôr deste mundo.

Mas se tolo é admiral-o,

A todo o mundo antepol-o,

Querer lá vel-o num throno,

Num leito dourado pol-o,

Alfim beijal-o e gozal-o,

Então, sim, quero ser tolo! (334-35)

Chamo logo a atenção para o registro poético que vim perseguindo até aqui e no qual o poema faz a transição da dicção cômica ou satírica-obscena para a essencialmente lírica. Em consonância com a forma popular da redondilha empregada nos nove sextetos, o poema faz confluir a notação prosaica ${ }^{17} \mathrm{com} o$ tom mais elevado. O prosaísmo comparece em expressões como o insulto recorrente ("tolo" e sua derivação, "toleirão"), as formas verbais "chiar" e "amolas" (no duplo sentido, literal e metafórico do termo) e, mesmo, um símile do tipo "qual canivete em rebolo." Mas a esses exemplos de coloquialidade, todos presentes logo na primeira estrofe, segue, nas demais, uma linguagem apuradíssima, com seleção de palavras raras, pouco usuais, como "alfim," e

${ }^{17}$ Obviamente, a notação prosaica não se confunde com o que se viu, anteriormente, nos poemas fesceninos. No máximo, pode ser aproximada de expressões como o "sô brejeiro" empregado, ironicamente, pelo Plutão de Moniz Barreto em um dos sonetos. 
imagens de cunho sublimizante, em sintonia com a expressão sentimental, traduzida em devoção amorosa, e a idealização da figura do amado. Pois este é tratado como ser angelical (e em sua hierarquia máxima, "seráfica," mas com um poder de sedução equiparável ao da falange que arrebatou o Mefisto goethiano), elevado, assim, às alturas por um amor devocional que chega a repor a dualidade platônica ou órfica entre corpo (=cárcere) e alma. ${ }^{18} \mathrm{O}$ sentimentalismo, angelismo e idealização lembram de perto o petrarquismo (também tributário da herança neoplatônica) reeditado pela segunda geração romântica em que nosso poeta-frei se encontra historicamente inscrito, ao lado de Álvares de Azevedo. É certo que um petrarquismo no qual se substitui o "eterno feminino" goethiano pelo moçoilo venerado.

Como ao longo das estrofes persiste a referência ao insulto ("tolo"), cria-se uma tensão de registros curiosa com esses termos mais elevados, de modo que, embora o poema se afaste do cômico, ele é composto por um híbrido de registros incomum nos essencialmente líricos. Trata-se, portanto, de um lirismo sui generis. Merece atenção o modo como o eu poético se reporta ao ser amado: "loiro moço[i]lo" (com a supressão da semivogal do ditongo em função da rima), "menino," "meu moço, anjinho feliz." Mais que afetividade e idealização, essas expressões parecem apontar para o estatuto juvenil do destinatário do loa amoroso. E embora não haja, em contrapartida, qualquer referência à idade do eu poético (descartada também qualquer associação biográfica), ele parece se afigurar como alguém mais maduro que o menino a quem se dirige. ${ }^{19}$ Essa

\footnotetext{
${ }^{18} \mathrm{O}$ orfismo encara o homem como um ser composto, essencialmente duplo. A alma é estranha ao corpo, de origem titânica, no qual se acha encarcerada, aspirando a uma salvação que é, precisamente, libertar-se dele e reintegrar-se no supra-individual. Essa separação brutal atesta, desse modo, como o orfismo contribuiu para a expressão mais característica do platonismo (seguindo adiante com o neoplatonismo), ao opor o mundo inferior dos sentidos ao universo divino das Ideias. Ver, a respeito, Gazzinelli.

19 Essa maturidade pode, muito bem, ser mais intelectual, subjetiva ou emocional, do que, objetivamente, etária. $\mathrm{O}$ eu lírico revela, assim, ser detentor de uma vivência, uma consciência ou experiência mais apurada ou aguçada que a de seu interlocutor. Uma maturidade dessa ordem não é única na poesia de sua geração, aliás. Em outro ensaio, busquei demonstrar como Álvares de Azevedo retoma a tópica do puer senex da hagiografia medieval e do esquema panegírico da tradição clássica para caracterizar o estatuto do gênio romântico adolescente (ou adulescenssenilis) representado tanto na sua poesia quanto na prosa. Nivelando "a polaridade jovem-velho," tal tópica enfatiza a precocidade do jovem em posse de um conhecimento muito além de sua idade. Algo nesse sentido pode ser associado ao eu lírico freiriano. Algo similar, inclusive, ocorre em outro poema do autor de Inspirações no claustro, intitulado "Pedido," no qual se tem, de um lado, um "belo jovem," cujo olhar ingênuo desconhece o que é violência e dor no mundo, na natureza e
} 
diferença ou assimetria etária faz pensar, na tradição, já referida de passagem, da poesia erótica grega, denominada de paidikón e assim definida por Ragusa: “canto erótico-encomiástico de um adulto a um 'belo menino' (paîs kalós), detentor do interesse sexual do amador, próprio do simpósio em que a presença de meninos, rapazes, era considerada um adorno necessário, por sua juventude e beleza, e desejável para a formação destes que ali observavam o comportamento e a vivência dos homens da aristocracia" ("A tradição" 86).

Nesse tipo de canção, seja na modalidade solo ou coral, o encômio tem a finalidade de seduzir o desejado menino (paîs) ou efebo (éphēbos)—expressões intercambiáveis na poesia-elogiando seus encantos "na expectativa de induzir uma resposta sexual" consensual (Ragusa, "A tradição" 187-212). Seria válido sustentar essa aproximação do poema freiriano com a tradição do paidikón, até porque há outras afinidades que podem ser sinalizadas, embora haja também diferenças substanciais que merecem destaque. De todo modo, essa tradição pode ser um termo de comparação válido para chamar atenção às especificidades do poema de Junqueira Freire.

Afora a diferença de idade entre o adulto amador e o jovem amado, outro traço afim ao paidikón é a ênfase dada ao olhar. ${ }^{20}$ Apesar de não ser exclusiva dessa tradição, essa "conexão entre olhos, o enamorar-se e o desejo sexual" (Rizzini 90) configurando "um motivo recorrente que atravessa a história da literatura grega" (Rizzini 90) é justificada por Ragusa a partir de um comentário de Aristóteles, válido para todo o catálogo de poemas dedicado ao tema. De acordo com o filósofo estagirita, "os amadores [toùs erastás] outra parte do corpo dos amados [erōménōn] não contemplam que não os olhos, pois neles habita a modéstia [aidō]" (Ragusa, "A tradição" 191). Essa relevância do épainos, "da

nos seres. Por isso, pode se entregar a "visões ditosas" e "mil esperanças gentis," acordando, assim, a falar de "amores com prazenteiro sorrir." De outro, ao contrário do "espírito inocente" desse seu interlocutor em cujo peito "não tocou a mão da dor" e por isso "pode bem pensar de amor," o eu lírico do poema tem "lutado contra a vida, / bebido noutro cálice de dores." É desse sofrimento e descrença que vem sua maturidade (independente da idade, se se pensar no citado estatuto de puer senex). Apesar do modo como se dirige ao interlocutor (nomeando-o como "belo jovem"), o poema "Pedido" não trata de um sentimento ou desejo homoerótico, como "Eu que te amo tão deveras." De modo explícito, o eu lírico alega que sua dor se deve ao fato de ele nunca ter experimentado "nos olhos d'alma / o trespassar dos olhos da donzela," não podendo, portanto, "pintar ardores que não senti por ela" (Poesias completas I, 39-40).

${ }^{20}$ De acordo com Ragusa, "na relação pederástica, o amador (erastēs) não pode ser jovem, nem velho, mas adulto, enquanto o amado (erōmenos) não pode ser adulto, nem velho, mas jovem” (“A tradição" 196). 
atenção aos olhos e ao olhar do elogiado, no imaginário grego," como um importante instrumento de "mediação entre amador e amado" na tradição poética erótica de sedução, parece estender-se para muito depois, portanto, conforme atesta o poema de Junqueira Freire.

Segundo Ragusa, no corpus dos paidiká mélicos, além dos olhos, há referências ao corpo do ser amado como um todo ("A tradição"). Há um fragmento de Anacreonte, que fala nas coxas, mas trata-se de uma especificação inusual. Projeta-se mais metaforicamente a beleza, com ênfase na delicadeza, na fragilidade e na juventude. Já nisso percebe-se uma pequena diferença no poema de Junqueira Freire face a essa tradição. Embora a terceira estrofe revele o olhar como desencadeador da sedução, logo traduzida na devoção amorosa a que reiteradamente reporta o poema, há, na quinta, outra parte do corpo do rapaz que prende o olhar do eu embevecido: o "queixinho bipartido." Porém, desse detalhe, o eu lírico logo parte para a contemplação hiperbolicamente prolongada do todo: "Quem embebido em seu todo / Horas, dias, gasto tem."

Outras diferenças significativas afloram no poema do Junqueira Freire em relação ao referido corpus, como seu contexto de enunciação, que nada revela de afim aos simpósios do paidikón. Mais significativa, contudo, é a reação do jovem a quem o eu lírico dedica seu amor. Nada aqui, obviamente, se aproxima do "ideal de reciprocidade, essencial ao simpósio e desejada pelo amador na tradição do paidikón. (Ragusa, Lira grega 94). Conforme ainda esclarece Ragusa, o conceito de reciprocidade (kháris) é um dos pilares de organização das relações sociais (e econômicas) no mundo grego arcaico e clássico, em todas as dimensões, incluindo a do erotismo. Especificando um pouco mais: "Se o erastes (o amador, o sedutor) oferece um dom ao eromenos (o amado)-dom este que pode ser a própria canção e sua imortalização nos versos, ou presentes outros, ou a paideia, a formação do jovem-, este deve retribuir. E sendo o amador o homem adulto, o que o amado lhe pode oferecer é o prazer erótico, a capitulação." ${ }^{21}$ No poema de Junqueira Freire, o amador até parece arriscar algo correspondente à canção imortalizadora do amado. Porém, de acordo com a sétima estrofe, ela, de certo modo, já está fadada ao fracasso, pois o amador desqualifica a própria criação, falando em "maus dois versos," responsáveis por desencadear, ao contrário da esperada consensualidade, a reação negativa do

\footnotetext{
${ }^{21}$ Transcrição de um comentário feito por Ragusa em outro lugar que não os ensaios citados.
} 
amado, que além de "amolar" e ofender, leva o louro moçoilo ao desprezo e ao furor contra o amante! Assim, ao invés da desejada kháris, tem-se, em suma, a atitude violentamente reativa; ao olhar contemplativo e devotado do amador, o "mirar tão furibundo" do amado, que contraria por completo a lição do filósofo estagirita.

Por último, destaco a diferença mais substancial do poema de Junqueira Freire em relação ao paidikón. Viu-se que este se constitui como um discurso essencialmente elogioso ao "belo menino" a ser seduzido - cuja voz, aliás, não é ouvida nos versos. No poema freiriano, de certo modo, a voz do jovem chega a ser reportada pelo eu lírico já pelo insulto ("tolo") que, afinal, parte daquele e reverbera em quase todas as estrofes. Mas a diferença interessante nesse caso é que, ao encômio pederástico, constitutivo do paidikón, soma-se um discurso lógico-argumentativo do eu lírico, de que o "avanço axioma certo" da oitava estrofe é a prova mais eloquente. Esse discurso visa não apenas demonstrar a improcedência da acusação de "tolo," como também reverter ou devolver, sutil e ironicamente, o epíteto ofensivo, em meio ao loa amoroso, àquele que originalmente o proferiu Por força da agudeza e da lógica argumentativa, o eu poético atesta que a reação ofensiva, essa sim, é própria de um "toleirão," completamente insensível à real dimensão dos sentimentos e intenções que ele devota ao moçoilo e que vão além do mais banal e da mera e imediata satisfação sexual—portanto "fora da contagião," no sentido, decerto, de hábito nocivo; vício que se comunica; doutrina má. Diante da atitude tão reativa e violenta em face a esse amor cuja grandeza é minuciosamente detalhada e ilustrada ao longo dos versos, o eu lírico constata, na penúltima estrofe, a frustração decisiva de sua realização em vida e a impossibilidade de ter um anjo que o acompanhe na passagem para o pós-morte. E nisso contraria o próprio modelo neoplatônico do amor petrarquista dominante na segunda geração romântica, na qual a recusa da posse física transpõe para o pós-morte o encontro "das almas" dos amantes, consumando uma forma de amor superior. ${ }^{22}$

Fiel à lógica argumentativa do todo, a última estrofe faz a síntese do que havia sido explanado e demonstrado nas anteriores. Agora, o epíteto de "tolo" pode até ser aceito ou mesmo desejado (“Então, sim, quero ser tolo!”), uma vez

\footnotetext{
${ }^{22}$ A respeito do petrarquismo no quadro da segunda geração romântica brasileira, notadamente em Álvares de Azevedo, ver Alves; Camilo (“Álvares de Azevedo”); e Santiago.
} 
que, por força da argumentação desenvolvida, é ressignificado no sentido da pureza e da grandeza do sentimento amoroso devotado pelo eu lírico ao moçoilo insensível, a quem, não obstante, admira (valendo atentar para a etimologia da palavra); a quem buscou e busca antepor a todo mundo; entronizar; dispor num leito de ouro e "alfim beijá-lo e gozá-lo."

Concluindo a presente abordagem, resgato sucintamente os procedimentos empregados nesse poema de Junqueira Freire que, apesar de isolado, marca, de fato, mudança significativa no discurso poético sobre o homoerotismo. Nele, confluem, em matéria de registro, prosaísmo e dicção elevada, sublimizante; ironia e lirismo; e, no que tange aos modelos e escolas literárias, sentimentalismo romântico, idealismo petrarquista, neoplatônica, e tradição do paidikón, juntamente com a racionalidade de um discurso lógico-argumentativo que faz pensar, antes, numa possível herança neoclássica, formando, ao fim, um híbrido de discursos, gêneros e escolas. ${ }^{23}$

Não há notícia de o poema ter circulado à época, nem em grupos restritos de leitores, como as coteries do tempo. De todo modo, contemporâneo e próximo que era dos outros dois poetas examinados, pode-se supor o curto-circuito que os versos de Junqueira Freire causariam mesmo se dirigidos ao petit comité composto pela "rapaziada" incitada por Moniz Barreto a execrar violentamente toda e qualquer manifestação de homoerotismo. Os poemas do Álbum e a rapaziada encarnam, sem dúvida, o "horizonte de expectativa" nas tertúlias masculinas do tempo, onde o tema até podia ser abordado, desde que em registro satírico obsceno. Seria impensável em outro tom: um tratamento sério e, mais ainda, lírico amoroso, romperia por completo com tal expectativa. É como se a tradição grega do paidikón não fizesse parte do repertório de então, soterrada, decerto, pela condenação cristã e pelo moralismo burguês.

A atitude do "loiro moçoilo" tem algum parentesco na da rapaziada, dada a violência com que hostiliza o sentimento amoroso devotado a ele pelo eu lírico. Isso mesmo que a mirada que lhe lança este último não vise - tal como o olhar libidinoso da persona de Rabelo, ao flagrar o "lindo rosto" de um rapaz por uma "greta fina"- - a posse efetiva ou a consumação sexual. Mas apesar de não ser

\footnotetext{
${ }^{23}$ Candido fala em "Conflito da forma e da sensibilidade em Junqueira Freire" pelo fato de o poeta ainda estar preso aos padrões clássicos, portanto sem se adequar completamente às demandas expressionais do romantismo (Formação 155). Esse conflito entre estéticas, visto como deficiência da obra freiriana, parece ter alcançado uma solução feliz, pelo menos no poema aqui analisado.
} 
ameaçadora, a atitude contemplativa contraria o esperado e causa estranhamento num horizonte em que o amor sublimado da convenção petrarquista só pode ter por alvo o "eterno feminino."

Enfim, comparado com os poemas satíricos de seus conterrâneos, muito embora Junqueira Freire positive o desejo homoafetivo, nem por isso consegue, como no paidikón, a aquiescência ou consensualidade do ser amado necessária à sua consumação. Ainda assim, reitero, o poema em questão representa um momento excepcional de afirmação dessa ordem de desejo na tradição poética local, que, talvez descontadas as contribuições da prosa oitocentista, viria mesmo a ser retomado como matéria de expressão e reflexão mais adensada apenas no século seguinte. ${ }^{24}$

\section{Obras citadas}

Alighieri, Dante. A divina comédia, tradução de Italo Eugenio Mauro, Ed. 34, 2001.

Alves, Cilaine, O belo e o disforme: Álvares de Azevedo e a ironia romântica. U de São Paulo, 1998.

Azevedo, Manuel Antônio Álvares de, Obras: prosa, edição de Jacy Monteiro, 2 vols., Garnier, 1862.

Barbo, Daniel. O triunfo do falo: homoerotismo, dominação, ética e política na Atenas clássica. E-papers, 2008.

Beurdeley, Cecile. L'amour bleu. Tradução de Michael Taylor, Evergreen e Benedikt Taschen, 1994.

Broca, Brito. "O poeta dos salões e o poeta da praça pública." Românticos, préromânticos, ultra-românticos: vida literária e Romantismo brasileiro. Polis, 1979, pp. 69-72.

\footnotetext{
${ }^{24}$ É certo que, na segunda metade do século XIX, a temática homoerótica ganha corpo, mas notadamente no romance, de que é exemplo Bom crioulo, de Adolfo Caminha. O enfoque predominantemente patológico, determinista, da época parece ter encontrado na prosa de ficção o gênero mais adequado para os "estudos de caso" então em voga. O tratamento lírico do tema, até onde sei, teria de aguardar pelas conquistas do Modernismo para alcançar uma dimensão mais adensada que a do poeta-frei beneditino. Vale, nesse sentido, comparar o poema de Freire com, por exemplo, a bela "Balatetta," de Mario Faustino (160-61), com que guarda certa afinidade, sem que se sustente qualquer diálogo intertextual efetivo.
} 
Camilo

Camilo, Vagner. "Proh pudor!... O riso obsceno." Risos entre pares: poesia e humor românticos. U de São Paulo/ Fundação de Amparo à Pesquisa do Estado de São Paulo, 1997, pp. 123-58.

-. "Álvares de Azevedo, o Fausto e o mito romântico do adolescente no contexto político-estudantil do Segundo Reinado." Itinerários, vol. 33, 2011, pp.61-108.

Campos, Haroldo de, Deus e o Diabo no Fausto de Goethe. Perspectiva, 1981.

Candido, Antonio, Formação da literatura brasileira: momentos decisivos. 2 vols. Itatiaia, 1981.

—. “A educação pela noite.” A educação pela noite e outros ensaios, Ática, 1987.

Culler, Jonathan, Theory of the Lyric. Harvard UP, 2015.

Curopos, Fernando. "Contra os queers, marchar, marchar!" Via Atlântica, São Paulo, no. 33, 2018, pp. 135-49.

Curtius, Ernst Robert. Literatura europeia e Idade Média Latina. Tradução de Teodoro Cabral e Paulo Rónai, U de São Paulo, 2013.

Faustino, Mário. O homem e sua hora e outros poemas. Companhia das Letras, 2002.

Franchetti, Paulo, "A poesia do eu: a poesia romântica." América Latina: palavra, literatura e cultura, 2 vols., edição de Ana Pizarro, U Estadual de Campinas/Memorial da América Latina, 1994, pp. 187-220.

Freire, Junqueira. Poesias completas. 2 vols., Edição de Roberto Alvim Corrêa, Valverde, 1944.

Gazzinelli, Gabriela, Fragmentos órficos. U Federal de Minas Gerais, 2007.

Goethe, Johann Wolfgang von. Fausto, tradução de Jenny Klabin Segall, Itatiaia, 1987.

Guimarães, Bernardo. Poesia erótica e satírica. Edição de Duda Machado. Imago, 1992.

Guiraud, Pierre. Les gros mots. Presses Universitaires de France, 1975.

Hansen, João Adolfo. A sátira e o engenho: Gregório de Matos e a Bahia do século XVII. Companhia das Letras/Secretaria de Estado da Cultura, 1989.

Hodgart, Matthew, La sátira. Guadarrama, 1969.

Kernan, Alvin, The Cankered Muse: Satire of the English Renaissance. Yale UP, 1962. 
Lepage, Yvan G., "François Villon et la homossexualité." Homosexual Themes in Literary Studies, edição de Wayne R. Dynes e Stephen Donaldson, Garland, 1992, pp. 203-24.

Merquior, José Guilherme, De Anchieta a Euclides: breve história da literatura brasileira. José Olympio, 1977.

Mott, Luiz, Homossexuais da Bahia: dicionário biográfico, séculos XVI-XIX. Grupo Gay da Bahia, 1999.

Muchembled, Robert. Uma história do Diabo: séculos XII-XX. Tradução de Maria Helena Kühner, Bom Texto, 2001.

Neto, João Ângelo Oliva, editor e tradutor. Priapeia grega, priapeia latina. Ateliê e U Estadual de Campinas, 2006.

Pires, Homero, Junqueira Freire: sua vida, sua época, sua obra. A Ordem, 1929.

Pellegrini, Leônidas. Álbum da rapaziada: o humor obsceno de Francisco Moniz Barreto. 2008. U Estadual de Campinas, Tese de mestrado, repositorio .unicamp.br/handle/REPOSIP/ 270273.

Preminger, Alex, e Terry V. F. Brogan, editores. The New Princeton Encyclopedia of Poetry and Poetics. Princeton UP, 1993.

Rabelo, Laurindo José da Silva. Obras completas. Poesias livres. Nacional, 1946.

—. Obras poéticas. Rio de Janeiro, 1882.

Ragusa, Giuliana, “A tradição do paidikón na mélica grega arcaica: testemunhos e canções." Phaos, vol. 17, no. 1, 2017, pp. 187-212.

—, trad. Lira grega: antologia da poesia arcaica. Hedra, 2009.

Rizzini, Ilaria. "Gli occhi di persuasione e la persuasione attraverso gli occhi." Quaderni Urbinati di Cultura Classica, vol. 62, 1999, pp. 87-97.

Romero, Silvio, História da literatura brasileira. 2 vols. Garnier, 1888.

Santiago, Emmanuel, A musa de espartilho: o erotismo na poesia parnasiana brasileira. 2016. U de São Paulo, Tese de doutoramento, doi: 10.11606/T.8.2016.tde-19122016-093102.

Solmsen, Friedrich, "The Powers of Darkness in Prudentius's 'Contra Symmachum': A Study of his Poetic Imagination.” Vigiliae Christianae, vol. 19, no. 4, 1965, pp. 237-57.

Zumthor, Paul. A letra e a voz: a 'literatura' medieval. Tradução de Jerusa Pires Ferreira, Companhia das Letras, 1993. 